\title{
PENINGKATAN KUALITAS PELAYANAN TOKO HIJAB AMIRA SURAKARTA DENGAN MENGGUNAKAN APLIKASI FASHION HIJAB BERBASIS ANDROID
}

\author{
Rachmawati Sunaringtyas Sarkoro ${ }^{1}$ \\ Wika Dewanta ${ }^{2}$ \\ AMIK Harapan Bangsa Surakarta \\ rachmawatisunaringtyas@gmail.com ${ }^{1}$ \\ wikadewanta@gmail.com ${ }^{2}$
}

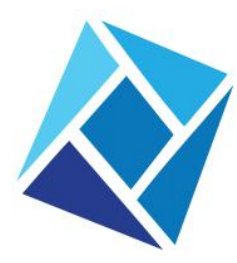

\section{Jurnal Nusantara} Aplikasi Manajemen Bisnis

http://ojs.unpkediri.ac.id/index.php/manaje men/index

E-ISSN : 2528-0929
P-ISSN : 2549 - 5291

Diterima: 24 September 2018

Revisi : 8 Oktober 2018

Disetujui: 13 Oktober 2018

https:DOI 10.29407/nusamba.v3i2.12453

\begin{abstract}
Tighter competition in selling muslimah fashion, especially hijab, demands seller to be able survive in determining sales strategy. In this case, hijab shop is as one of providers about muslimah needs must be able to capture opportunities in providing Muslim fashion. Android is an alternative software chosen for assisting Amira hijab shop in Surakarta in order to do service innovation hopes giving excellent service and hadling customers complaint. The Fashion Hijab application design of Amira hijab shop in Surakarta can be done by using online shop website with base of CMS Wordpress resulting Toko Hijab Amira Surakarta named hijabamira.com, which is continued by doing convertion from website to android aplication using Website 2 APK Builder Pro. Analysis of fashion hijab application after implementation of Toko Hijab Amira Surakarta is done by using models of information success system DeLone and McLean are used to measure how high is the affect of system quality,information quality towards customer's quality, and service quality towards customer's satisfaction as system user who continually affects benefit gotten by Toko Hijab Amira Surakarta. This research uses descriptive quantitative approach along with convenience sampling technique. The sample and population in this research were 70 customers of Toko Hijab Amira Surakarta and collection technique is done by observation and questionnaire after implementing Fashion Hijab android-based application. By using Structural Equation Modelling (SEM) research method, it can know the relationship precision among variables of system, information, and service qualities; customer; customer's satisfaction; and the affect of Toko Hijab Amira Surakarta 's benefit.

Keywords : Fashion Hijab application, DeLone and McLean Model, Stuctural Equation Modelling (SEM)
\end{abstract}

\begin{abstract}
Abstrak
Persaingan yang semakin ketat dalam penjualan busana muslimah khususnya fashion hijab menuntut penjual untuk mampu mengambil langkah yang tepat dalam menentukan strategi penjualan. Dalam hal ini Toko hijab sebagai salah satu penyedia perlengkapan muslimah harus mampu menangkap peluang dalam menyediakan fashion muslimah. Android merupakan alternatif perangkat lunak yang dipilih untuk membantu Toko Hijab Amira Surakarta dalam melakukan inovasi pelayanan diharapkan dapat menjadi salah satu strategi penjualan dalam memberikan pelayanan prima dan mengatasi keluhan pelanggan. Rancang bangun aplikasi fashion hijab Toko Hijab Amira Surakarta dapat dilaksanakan dengan menggunakan website toko online berbasis CMS Wordpress dengan hasil berupa website Toko Hijab Amira Surakarta dengan nama hijabamira.com, yang dilanjutkan dengan melakukan konversi dari website ke aplikasi android dengan menggunakan Website 2 APK Builder Pro. Analisa aplikasi fashion hijab setelah implementasi dilakukan dengan menggunakan Information success system DeLone and McLean models yang digunakan untuk mengukur seberapa besar pengaruh kualitas sistem, kualitas informasi dan kualitas pelayanan terhadap kepuasan pelanggan sebagai pengguna sistem yang selanjutnya akan berpengaruh pada keuntungan yang diperoleh Toko Hijab Amira Surakarta. Penelitian ini menggunakan pendekatan deskriptif kuantitatif dengan teknik convenience sampling (sampel kenyamanan). Sampel dan populasi penelitian adalah pelanggan Toko Hijab Amira Surakarta sebanyak 70 pelanggan dan teknik pengumpulan data melalui observasi dan kuesioner setelah implementasi aplikasi fashion hijab berbasis android. Dengan menggunakan metode penelitian Structural Equation Modelling (SEM) dapat diketahui ketepatan hubungan antar variabel kualitas sistem, kualitas informasi, kualitas pelayanan, terhadap pengguna dan kepuasan pengguna serta pengaruh terhadap keuntungan Toko Hijab Amira Surakarta.
\end{abstract}

Kata kunci : aplikasi fashion hijab, Model DeLoan dan McLean, Stuctural Equation Modelling (SEM) 


\section{PENDAHULUAN}

Fashion mencerminkan gaya hidup suatu komunitas masyarakat. Selain itu Fashion juga dapat mengekspresikan identitas kelompok masyarakat tertentu yang merupakan bagian dari kehidupan sosial. Gaya hidup menuntut masyarakat untuk mengikuti setiap detail perubahannya pada era modern ini. Fashion menjadi senjata dalam setiap berpenampilan, baik fashion busana atau hijab. Seiring dengan berkembangnya dunia fashion muslim, mode busana muslimah semakin bervariasi yang didukung desainerdesainer yang khusus merancang busana muslimah. Fashion muslimah yang semakin bervariasi mendorong remaja-remaja muslimah untuk berbusana muslim. Berbusana muslimah selain untuk menutup aurat, memperindah penampilan juga dapat menggambarkan status sosial seseorang. Agama islam juga menganjurkan umatnya untuk menutup aurat (berbusana muslim) baik untuk kaum pria atau wanita yang diatur dalam $\mathrm{Al}$ Qur'an surat Al-Azhab: 59. Semakin banyaknya pemakai busana muslimah, membuka peluang para pebisnis untuk mengembangkan bisnisnya dalam fashion muslimah, contohnya untuk fashion hijab.

Persaingan yang semakin ketat dalam penjualan busana muslimah khususnya fashion hijab menuntut penjual untuk mampu mengambil langkah yang tepat dalam menentukan strategi penjualan agar mampu bertahan dalam industri fashion hijab. Strategi penjualan yang dilakukan harus mampu meningkatkan kepuasan pelanggan. Kepuasan pelanggan merupakan hal penting dalam mengembangkan usaha fashion hijab. Kepuasan pelanggan sangat erat kaitannya dengan kualitas pelayanan. Jika kualitas pelayanan baik maka konsumen akan merasa puas dan meningkatkan loyalitas pelanggan untuk kembali lagi ke toko fashion hijab. Dalam hal ini Toko hijab sebagai salah satu penyedia perlengkapan muslimah harus mampu menangkap peluang dalam menyediakan fashion muslimah. Toko hijab harus mampu mengikuti perkembangan mode fashion muslimah yang sesuai dengan keinginan pelanggan. Toko Hijab Amira Surakarta adalah sebuah toko yang bergerak dalam bidang penjualan fashion hijab. Saat ini rata-rata penjualan hijab di Toko Hijab Amira Surakarta adalah 1750 potong hijab per bulan dengan beraneka macam model hijab. Semakin meningkatnya permintaan pelanggan tentang variasi fashion hijab dan cara pemakaian hijab yang sesuai model terbaru, menuntut pemilik toko untuk membuat strategi penjualan yang efektif dan efisien. Selain itu, bervariasinya dunia fashion hijab, menuntut para pegawai Toko Hijab Amira Surakarta untuk lebih lihai dalam penerapan model busana fashion hijab yang sesuai dengan permintaan pelanggan.

Semakin meningkatnya pemintaan pelanggan menuntut pemilik usaha untuk selalu melakukan inovasi dalam memberikan pelayanan yang terbaik kepada pelanggan. Kualitas pelayanan berfokus pada upaya pemenuhan kebutuhan dan keinginan pelanggan, serta ketepatan penyampaiannya untuk mengimbangi harapan pelanggan. (Rust dalam Tjiptono, 2005). Setiap pelaku usaha di tiap kategori bisnis dituntut 
untuk memiliki kepekaan terhadap setiap perubahan yang terjadi dan menempatkan orientasi kepada kepuasan pelanggan sebagai tujuan utama. (Kotler, 2005).

Android merupakan alternatif perangkat lunak yang dipilih untuk membantu Toko Hijab Amira Surakarta dalam melakukan inovasi pelayanan, dengan alasan android cenderung digunakan pada perangkat mobile seperti smartphone dan tablet pc, peran pengguna android dapat memaksimalkan fungsi dan performa smartphone dalam berbagai macam aplikasi (Nazarudin Safaat ,2012). Dengan membuat aplikasi di android, pelayan dapat berkomunikasi dengan pelanggan untuk memenuhi variasi model hijab sesuai dengan keinginan pelanggan. Selain itu, Android merupakan suatu media komunikasi yang tidak asing di masyarakat, serta pengaplikasiannya sangat mudah dan cepat. Dengan adanya android yang disambungkan dengan internet, dapat membantu masyarakat dalam pemenuhan kebutuhan di bidang pendidikan, kesehatan, politik bahkan di dunia fashion yang menjadi daya tarik masyarakat.

Strategi penjualan Toko Hijab Amira Surakarta dengan menggunakan Aplikasi Fashion Hijab berbasis android diharapkan dapat memberikan pelayanan prima dan mengatasi keluhan pelanggan. Setelah melakukan implementasi aplikasi fashion hijab di Toko Hijab Amira Surakarta selama dua bulan, penulis ingin mengetahui seberapa besar pengaruh kualitas sistem, kualitas informasi dan kualitas pelayanan terhadap kepuasan pelanggan sebagai pengguna sistem yang selanjutnya akan berpengaruh pada keuntungan yang diperoleh Toko Hijab Amira Surakarta. Untuk menganalisa aplikasi fashion hijab ini, penulis menerapkan Information success system DeLone and McLean model yang dapat digunakan untuk mengukur sejauh mana penerapan sebuah sistem informasi. Oleh karena itu, penulis tertarik untuk melakukan penelitian yang berjudul "Peningkatan Kualitas Pelayanan Toko Hijab Amira Surakarta dengan Menggunakan Aplikasi Fashion Hijab Berbasis Android".

\section{KAJIAN LITERATUR}

Fashion Busana

Setiap orang mempunyai gaya berpakaian setiap hari yang berbeda-beda, baik itu pada saat kerja, saat menghadiri acara tertentu ataupun dalam kehidupan sehari-harinya yang digunakan untuk mengikuti suatu budaya atau mode dalam menunjang penampilan atau gaya busana merupakan pengertian dari fashion. Kata Fashion sendiri berasal dari bahasa Inggris yang dapat diartikan sebagai mode, model, cara, gaya ataupun kebiasaan (Sora N, 2015).

Hijab adalah suatu benda yang masih sebatas sebagai fungsi teknis yang berarti masih sebatas sebuah benda yang memiliki fungsi untuk menutupi bagian tubuh yang dilarang untuk dilihat orang lain, untuk menghindari maksiat bagi yang melihat (Zerlina Lalage, 2014). Dalil dalam suatu agama memberikan ketentuan mengenai hijab adalah kain penutup kepala sehingga kain menjulur hingga dada. Berdasarkan referensi diatas dapat 
disimpulkan bahwa Hijab merupakan salah satu bagian dari fashion yang berupa kain besar yang menutupi kepala hingga dada agar tidak terlihat bentuk wajah dari seorang muslimah. Hijab juga diartikan sebagai penutup aurat wanita. Pemakaian model hijab yang serasi dengan busana dalam berbagai situasi merupakan Style dalam berhijab pada seorang muslimah. Ada yang lebih menyukai style yang sederhana juga tidak sedikit yang menyukai style berkerudung yang mewah. Oleh karena itu pemilihan style berhijab yang tepat untuk situasi serta kondisi yang berbeda-beda ini dapat memberikan kesan berhijab yang serasi.

\section{Kualitas Sistem Informasi}

Kualitas sistem informasi merupakan karakteristik dari informasi yang melekat mengenai sistem itu sendiri (DeLone dan McLean, 1992). Kualitas sistem informasi juga didefinisikan dalam Davis et al. (1989) dan Chin dan Todd (1995) sebagai perceived ease of use yang merupakan tingkat seberapa besar teknologi komputer dirasakan relatif mudah untuk dipahami dan digunakan. Pengguna harus dapat menguasai sistem informasi, sehingga mereka dapat bekerja secara efektif. Sistem informasi yang berkualitas idealnya telah melewati fase quality assurance dan control, yang berarti sistem informasi telah melewati fase development. Kriteria dan parameter pada pengukuran kualitas sistem informasi menjadi serangkaian kegiatan/aktifitas dengan menggunakan metode tertentu.

\section{Kualitas Informasi}

Kualitas informasi adalah tingkat dimana informasi memiliki karakteristik isi, bentuk, dan waktu yang memberikan nilai untuk para pemakai akhir tertentu (O’Brien, 2005). Kualitas informasi merupakan kualitas output yang berupa informasi yang dihasilkan oleh sistem informasi yang digunakan (Rai et al., 2002). Liu dan Arnett (2000) menyatakan bahwa informasi dengan kualitas terbaik akan meningkatkan kegunaan persepsi pengguna dan meningkatkan penggunaan sistem informasi. Kualitas informasi juga dapat dilihat dengan adanya potensi menghasilkan informasi yang tidak terbatas baik dalam organisasi maupun luar organisasi (Barnes et al., 2003).

Kualitas Pelayanan

DeLone dan McLean (2003) menggambarkan kualitas pelayanan yang dipersepsikan oleh pengguna, yang diukur dengan lima indikator yang diadaptasi dari bidang pemasaran (SERVQUAL) yaitu tangibles, reability, responsiveness, assurance, emphathy (dikutip dari Wahyudi, R. Astuti, E.S. Riyadi 2012). Kualitas pelayanan yang baik akan meningkatkan kepuasan pelanggan. Setiap unit usaha harus memperhatikan kualitas pelayanan yang diberikan kepada konsumennya, karena pelayanan merupakan faktor penting dalam setiap usaha. Pelayanan yang memuaskan pelanggan adalah pelayanan yang diterima atau dirasakan pelanggan sesuai atau bahkan melebihi harapan pelanggan. 
Pelayanan akan mengecewakan pelanggan jika pelayanan yang diterima oleh pelanggan tidak sesuai atau berada di bawah harapan pelanggan.

\section{Kepuasan Konsumen}

Kepuasan berkaitan dengan pengalaman dalam penggunaan produk maupun jasa pada tahap pasca pembelian, kepuasan seseorang bergantung pada perbedaan antara harapan dengan ekspektasi konsumen (discrepancy theory), dapat juga merupakan perbedaan antara keadilan dan tidaknya terhadap suatu situasi (equity theory), atau merupakan dua hal yang berbeda antara kepuasan dan ketidakpuasan seseorang (Choi dan Kim, 2013).Perusahaan dapat menggunakan metode- metode untuk mengukur kepuasan konsumen, sehingga langkah-langkah dan strategi dapat diambil perusahaan dalam mengembangkan usahanya. Dalam proses pemasaran sangat diperlukan pengukuran kepuasan konsumen.

\section{Intensitas Penggunaan (Intensity Of Use)}

Intensitas penggunaan menjelaskan tentang besarnya frekuensi penggunaan dalam memanfaatkan sistem informasi fashion hijab (Radityo Dkk, 2007). Pengguna sistem informasi fashion hijab adalah konsumen Toko Hijab Amira Surakarta.

\section{Net Benefits}

Net benefits menjelaskan bagaimana pengaruh kualitas kinerja dari pengguna terhadap penggunaan sistem informasi diantaranya adalah produktivitas, efisiensi dan efektivitas kinerja. (Radityo Dkk, 2007).

\section{Android}

Peresmian Android pada tahun 2007 bersamaan dengan terbentuknya Open Handset Alliance-konsorsium hardware, software, dan perusahaan telekomunikasi yang ditujukan untuk memajukan standar perangkat selular (Hp Area, 2016). Smartphone yang tersedia untuk publik pertama kalinya yang menjalankan Android adalah HTC Dream, yang dirilis pada tanggal 22 Oktober 2008 untuk pertama kalinya diresmikan smartphone untuk publik yang dapat menjalankan android yaitu HTCDream yang merupakan telepon pintar atau komputer tablet yang menggunakan sistem operasi berbasis Linux yang dirancang untuk perangkat bergerak layar sentuh.

\section{Model Sistem Informasi DeLone dan McLean}

Pada tahun 1992, karya tulis ilmiah karya DeLone dan McLean yang berisi tentang pengetahuan serta sebuah struktur kepada "variabel dependen" dalam riset terkait sistem informasi dipublikasikan oleh DeLone \& McLean. DeLone \& McLean mengajukan sebuah model interaktif dan taksonomi sebagai kerangka kerja untuk melakukan konseptualisasi dan operasionalisasi keberhasilan sistem informasi (D\&M IS Success Model). Setelah 
penelitian yang dilakukan oleh DeLone \& McLean, kemudian muncul berbagai karya ilmiah serta konferensi-konferensi yang menggunakan D\&M IS Success Model dalam berbagai hal, termasuk yang terkait dengan sistem informasi, hal ini menandakan adanya kebutuhan akan sebuah kerangka kerja yang komprehensif untuk mengintegrasikan hasil penemuan dan riset terkait sistem informasi. (DeLone \& McLean, 2002). D\&M IS Success Model merupakan pengukuran kesuksesan dan efektivitas dari sistem informasi yang digunakan untuk memahami nilai-nilai dan keberhasilan dalam pengelolaan sistem informasi. Sejak tahun 1992, D\&M IS Success Model berperan dalam perubahan dan perkembangan penelitian- penelitian teoritis dan empiris. Pada tahun 2000, D\&M IS Success Model diteliti lagi dengan tujuan untuk memeriksa dan memformulasikan kembali D\&M IS Success Model dan langkah-langkah praktik sistem informasi dalam riset-riset yang telah dilakukan sebelumnya. Gambar 1 menunjukkan model yang diajukan oleh DeLone \& McLean pada tahun 1992

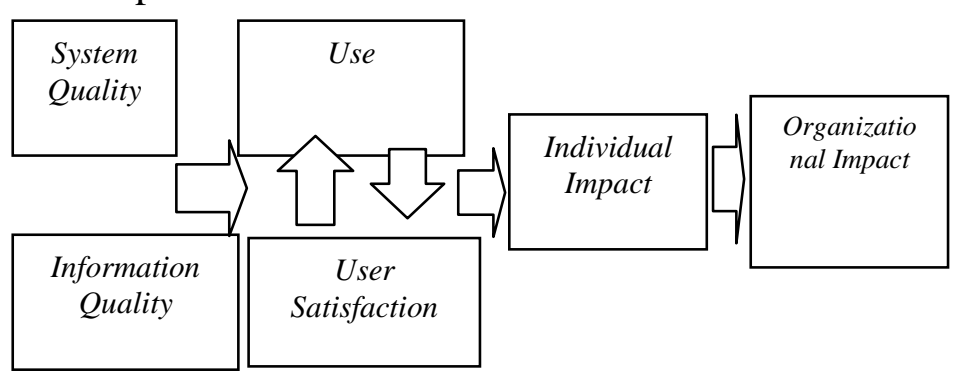

Gambar 1. Model Riset Awal DeLone \& McLean Tahun 1992

\section{Structural Equation Modelling}

Setelah dilakukan uji instrument pengumpulan data pada penelitian langkah selanjutnya adalah melakukan uji hipotesis penelitian. Model analisis data yang akan digunakan dalam penelitian adalah teknik analisis SEM (Structural Equation Modelling) yang digunakan untuk menguji ketepatan hubungan antar variabel. Suatu teknik analisis yang digunakan untuk spesifikasi model dan estimasi model dalam hubungan linear antar variabel (MacCallum dan Austin, 2000 dalam Kristiono, 2015). Pengukuran dependent dan independent construct, serta hubungan variabel indikator dengan construct atau variabel laten dapat dilakukan dengan menggunakan Structural Equation Modelling (SEM). Hubungan tiap faktor yang dijelaskan dalam suatu struktur hubungan merupakan pengertian dari struktur model. (Ramadiani, 2010). Untuk menilai structural model dapat dilihat nilai R-Squares untuk setiap variabel laten endogen sebagai kekuatan prediksi dari model structural (Latan \& Ghozali,2012 dalam Kristiono, 2015,h 14 ). 


\section{METODE PENELITIAN}

Analisa (Analysis)

Analisa merupakan kegiatan mengidentifikasi berbagai kebutuhan perangkat lunak untuk menentukan spesifikasi fungsi sistem, kinerja sistem, dan kendala sistem.

Pada tahap Analysis ini penulis menggunakan analisis PIECES (Performance, Information, Economics, Control, Efficiency, dan Service) (Hanif Al Fatta, 2007). Analisis PIECES digunakan sebagai dasar untuk mendapatkan pokok permasalahan merancang dan membuat suatu aplikasi fashion hijab di Toko Hijab Amira Surakarta.

a) Performance (Kinerja)

Analisa kemampuan sistem dalam menyelesaikan tugas dengan cepat sehingga sasaran dapat segera tercapai disebut dengan kinerja.

Tabel 1. Analisa Kinerja

\begin{tabular}{|c|c|}
\hline Sistem Lama & Sistem Baru \\
\hline $\begin{array}{l}\text { Untuk pencarian fashion hijab mengandalkan } \\
\text { buku pedoman hijab dan sinyal wifi untuk } \\
\text { search ke internet }\end{array}$ & $\begin{array}{l}\text { Hanya cukup membuka aplikasi android } \\
\text { dan mencari menu fashion hijab yang } \\
\text { telah di pasang. }\end{array}$ \\
\hline
\end{tabular}

b) Information (Informasi)

Analisa informasi ini adalah suatu hal yang penting karena dengan adanya suatu informasi ini semua kalangan dapat menentukan langkah selanjutnya yang akan diambil.

Tabel 2. Analisa Informasi

\begin{tabular}{ll}
\hline \multicolumn{1}{c}{ Sistem Lama } & \multicolumn{1}{c}{ Sistem Baru } \\
\hline Informasi produk fashion hijab Toko Amira & Informasi produk fashion hijab Toko \\
diperoleh dari whattsup group dan datang & Amira dapat diperoleh dalam aplikasi \\
langsung ke Toko Amira. & fashion hijab. \\
\hline
\end{tabular}

c) Economy (Ekonomi)

Analisa ekonomi adalah penilaian sistem atas keuntungan yang akan didapatkan apabila aplikasi ini digunakan dengan sebagaimana mestinya.

\begin{tabular}{lll}
\hline \multicolumn{5}{c}{ Tabel 3. Analisa Ekonomi } \\
\hline Sistem Lama & \multicolumn{2}{c}{ Sistem Baru } \\
waktu yang lama dalam mencari model hijab & fashion hijab sehingga cukup cepat, \\
yang sesuai, terkadang ada costumer yang tidak & pelayanan akan menjadi prima dan banyak \\
jadi membeli dikarenakan lamanya dalam & yang datang untuk membeli hijab tersebut. \\
proses pelayanan dan pencarian model. &
\end{tabular}

d) Control (Pengendalian)

Analisa pengendalian digunakan untuk menganalisa sistem yang didasarkan pada segi kemudahan akses dan penggunaan oleh customer. 


\section{JURNAL NUSAMBA VOL.3 NO.2 Oktober 2018}

Tabel 4. Analisa Pengendalian

\begin{tabular}{|c|c|}
\hline Sistem Lama & Sistem Baru \\
\hline $\begin{array}{l}\text { Menggunakan internet sangat rumit dan } \\
\text { membingungkan bagi orang awam. }\end{array}$ & $\begin{array}{l}\text { Dengan android penggunaan sangat } \\
\text { mudah serta akses yang sesuai dengan } \\
\text { aplikasi lainnya seperti saat akses play } \\
\text { music, play film, kontak, dll }\end{array}$ \\
\hline
\end{tabular}

e) Efficiency (Efisiensi)

Analisa efisiensi berhubungan dengan sumber tersebut dapat digunakan secara maksimal.

Tabel 5. Analisa Efisiensi

\begin{tabular}{ll}
\hline \multicolumn{2}{c}{ Sistem Lama } \\
\hline Waktu pelayanan yang cukup lama, karena & Waktu pelayanan yang cepat, karena \\
pegawai harus mencari produk hijab yang & menggunakan media Smartphone \\
diinginkan oleh pelanggan. & yang sebagian besar orang \\
& memilikinya Pelanggan dapat \\
& memilih produk melalui aplikasi \\
& fashion hijab yang tersedia di \\
& smartphone. Jadi, dapat mengefisien- \\
& sikan waktu pelayanan.
\end{tabular}

f) Service (Pelayanan)

Analisa pelayanan menekankan pada kategori yang beragam dan yang dipilih merupakan peningkatan pelayanan yang lebih baik terhadap pelanggan dan pastinya akan membawa nama baik pula bagi pegawai maupun perusahaan.

Tabel 6. Analisis Pelayanan

\begin{tabular}{lll}
\hline Sistem Lama & \multicolumn{2}{c}{ Sistem Baru } \\
\hline Pelayanan cukup baik, karena pegawai berusaha & Pelayanan sangat baik, selain adanya \\
memberi pelayanan yang sebagaimana & aplikasi, pegawai juga menggunakan \\
mestinya, tapi jika pelanggan tidak berkenan & Smartphone yang pastinya pelanggan akan \\
karena pelayanan yang lama, hal ini & sangat dihargai. Pelayanan prima akan \\
menyebabkan kerugian dalam penjualan hijab. & mudah diterapkan oleh pegawai.
\end{tabular}

\section{Pembuatan Aplikasi Fashion Hijab Berbasis Android}

Pembuatan aplikasi android ini dimulai dari pembuatan website toko online berbasis CMS Wordpress dengan menggunakan template premium toko online yang sudah dimiliki sebelumnya oleh peneliti sebagai web developer, dan selanjutnya website yang telah dibuat dikonversikan menjadi aplikasi android (APK) menggunakan perangkat lunak pihak ketiga yang bernama Website 2 APK Builder Pro yang juga sudah dimiliki sebelumnya oleh peneliti.

Implementasi

Pada tahap implementasi penulis merancang sebuah sistem yang akan digunakan untuk menyelesaikan masalah yang sudah tertera pada rumusan masalah. Implementasi dilakukan dengan membagikan aplikasi fashion hijab kepada pelanggan Toko Hijab Amira Surakarta yang sudah memiliki kartu pelanggan. 


\section{Perancangan Model}

Pada penelitian ini, penulis membangun sebuah model yang diadopsi dari model penelitian Wang dan Liao (2008) yang mengembangkan model dari DeLone dan McLean (2003) mengenai keberhasilan sistem informasi yang digunakan dalam pelayanan kualitas. Model penelitian ini menyebutkan bahwa information quality, systems quality, service quality akan berpengaruh pada user dan user satisfaction dan selanjutnya akan mempengaruhi net benefit.

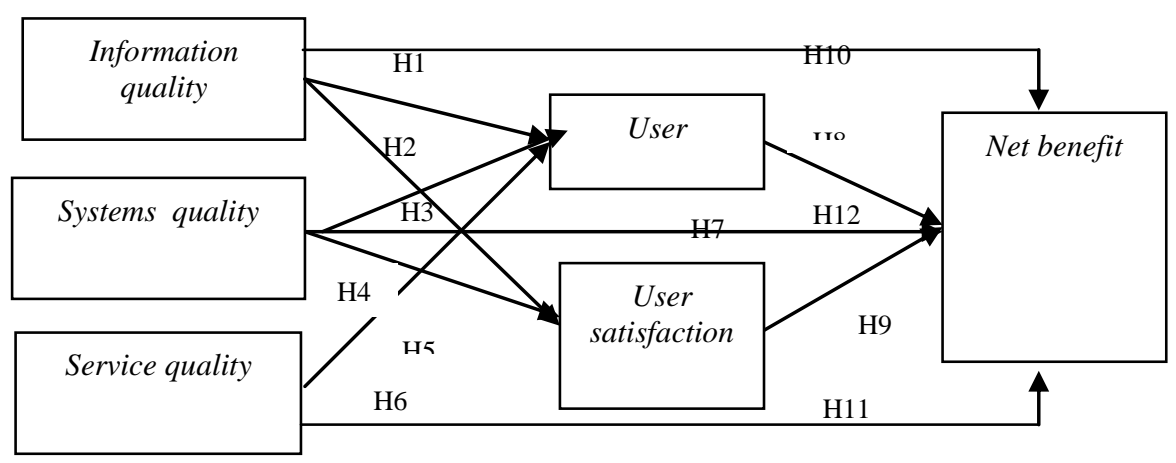

Gambar 2. Model Penelitian Wang dan Liao (2008)

Dengan hipotesis penelitian sebagai berikut :

$\mathrm{H}_{1}$ : Kualitas informasi (information quality) berpengaruh positif terhadap pengguna sistem (user)

$\mathrm{H}_{2}$ : Kualitas informasi (information quality) berpengaruh positif terhadap kepuasan pengguna sistem (user satisfaction)

$\mathrm{H}_{3}$ : Kualitas sistem (systems quality) berpengaruh positif terhadap pengguna sistem (user)

$\mathrm{H}_{4}$ : Kualitas sistem (systems quality) berpengaruh positif terhadap kepuasan pengguna sistem (user satisfaction)

$\mathrm{H}_{5}$ : Kualitas pelayanan (service quality) berpengaruh positif terhadap pengguna sistem (user)

$\mathrm{H}_{6}$ : Kualitas pelayanan (service quality) berpengaruh positif terhadap kepuasan pengguna sistem (user satisfaction)

$\mathrm{H}_{7}$ : Pengguna sistem (user) berpengaruh positif terhadap kepuasan pengguna sistem (user satisfaction)

$\mathrm{H}_{8}$ : Pengguna sistem (user) berpengaruh positif terhadap hasil akhir (net benefit)

$\mathrm{H}_{9}$ : Kepuasan pengguna sistem (user satisfaction) akan berpengaruh positif terhadap hasil akhir (net benefit)

$\mathrm{H}_{10}$ : Kualitas informasi (information quality) berpengaruh secara langsung terhadap hasil akhir (net benefit)

$\mathrm{H}_{11}$ : Kualitas sistem (system quality) berpengaruh secara langsung terhadap hasil akhir (net benefit) 
$\mathrm{H}_{12}$ : Kualitas pelayanan (service quality) berpengaruh secara langsung terhadap hasil akhir (net benefit)

$\mathrm{H}_{13}$ : Kualitas informasi (information quality) berpengaruh secara tidak langsung terhadap hasil akhir (net benefit) dengan variabel mediasi pengguna sistem (user)

$\mathrm{H}_{14}$ : Kualitas sistem (system quality) berpengaruh secara tidak langsung terhadap hasil akhir (net benefit) dengan variabel mediasi pengguna sistem (user)

$\mathrm{H}_{15}$ : Kualitas pelayanan (service quality) berpengaruh secara tidak langsung terhadap hasil akhir (net benefit) dengan variabel mediasi pengguna sistem (user)

$\mathrm{H}_{16}$ : Kualitas informasi (information quality) berpengaruh secara tidak langsung terhadap hasil akhir (net benefit) dengan variabel mediasi kepuasan pengguna sistem (user satisfaction)

$\mathrm{H}_{17}$ : Kualitas sistem (system quality) berpengaruh secara tidak langsung terhadap hasil akhir (net benefit) dengan variabel mediasi kepuasan pengguna sistem (user satisfaction)

$\mathrm{H}_{18}$ : Kualitas pelayanan (service quality) berpengaruh secara tidak langsung terhadap hasil akhir (net benefit) dengan variabel mediasi kepuasan pengguna sistem (user satisfaction)

Lokasi dan Waktu Penelitian

Studi kasus pada penelitian dengan judul Peningkatan Kualitas Pelayanan di Toko Hijab Amira Surakarta Dengan Menggunakan Aplikasi Fashion Hijab Berbasis Android ini berlokasi di Toko Hijab Amira Surakarta dengan Alamat di Jl. Srigading 1 No. 8 Turisari, Mangkubumen, Banjarsari, Surakarta dan cabang Toko Hijab Amira Surakarta di Pusat Grosir Beteng Surakarta.

Populasi dan Sampel

Pelanggan Toko Hijab Amira Surakarta Surakarta adalah konsumen yang telah melakukan proses pembelian sebesar Rp. 100.000,00. Pelanggan tersebut akan mendapatkan kartu pelanggan dari Toko Hijab Amira Surakarta. Saat ini jumlah pelanggan di Toko Hijab Amira Surakarta sudah mencapai 210 pelanggan. Berdasarkan jenis datanya, penelitian ini menggunakan pendekatan kuantitatif, penelitian kuantitatif bermaksud untuk menjelaskan desain penelitian secara sistematis, mempunyai struktur dan mempunyai rencana. Sedangkan jenis penelitian adalah penelitian deskriptif, yang berusaha untuk memecahkan masalah berdasarkan data yang tersedia.

Tujuan utama dari penelitian ini untuk menggambarkan secara sistematis fakta dan karakteristik obyek dan subyek yang diteliti secara tepat. Penelitian ini merupakan penelitian deskriptif kuantitatif yang menafsirkan data yang berkaitan dengan situasi yang terjadi. Pengumpulan data mengenai kualitas pelayanan Toko Hijab Amira Surakarta dilakukan dengan menyebarkan kuesioner tentang kualitas pelayanan setelah implementasi aplikasi fashion hijab. Penelitian ini menggunakan teknik convenience sampling (sampel kenyamanan) yang merupakan kumpulan individu, elemen atau peristiwa yang sudah 
langsung tersedia, dan dapat langsung digunakan untuk penelitian menurut Morissan (dikutip dalam Kristiono,2015). Sampel responden pada penelitian setelah implementasi aplikasi fashion hijab diambil $30 \%$ dari populasi pelanggan Toko Hijab Amira Surakarta (Arikunto, 2008) yaitu sebanyak 70 pelanggan yang dianggap dapat mewakili populasi pelanggan di Toko Hijab Amira Surakarta.

Variabel dan Indikator Penelitian

Setelah diterapkan aplikasi fashion hijab di Toko Hijab Amira Surakarta selama dua bulan, kemudian dilakukan penelitian lanjutan dengan melakukan penyusunan kuesioner dan penyebaran kuesioner kepada pelanggan untuk meneliti apakah kualitas pelayanan dan jumlah pelanggan di Toko Hijab Amira Surakarta dapat mengalami peningkatan. Variabel penelitian pada penelitian ini terdiri dari variabel independen, variabel dependen dan variabel intervening. Variabel independen terdiri dari kualitas sistem (system quality), kualitas informasi (information quality), dan kualitas pelayanan (service quality), variabel dependen yaitu hasil akhir (net benefit), sedangkan variabel intervening berupa penggunaan sistem (user), kepuasan penggunaan sistem (user satisfaction) setelah menggunakan aplikasi.

Pendefinisian variabel penelitian sebagai berikut :

- Kualitas sistem (System quality) dapat dilihat dari lima (5) sub-sub sistem sebagai berikut : kemudahan untuk digunakan (ease of use), kemudahan untuk diakses (system flexibility), kecepatan akses (response time), ketahanan dari kerusakan (system reliability), dan keamanan sistem (security)

- Kualitas informasi (information quality) dapat dilihat dari empat (4) sub sistem, yakni keakuratan informasi (accuracy), ketepatan waktu (timeliness), kelengkapan informasi (completeness) dan penyajian informasi (format).

- Kualitas pelayanan (service quality), dapat dilihat dari lima (5) sub-sub sistem, antara lain: tampilan fisik (tangibles), keandalan pelayanan (service reliability), kesigapan petugas (responsiveness), jaminan pelayanan (assurance) dan kepedulian petugas (empathy).

- Kepuasan pengguna (user satisfaction), dapat dilihat dari tiga (3) sub-sub sistem, antara lain : akurasi, konten dan format penyajian

- Intensitas untuk menggunakan sistem informasi fashion hijab (user), dapat dilihat dari dua (2) sub-sub sistem, antara lain : frekuensi pemakaian dan durasi waktu pemakaian.

- Keuntungan yang diperoleh (Net Benefit) dapat dilihat dari empat (4) sub-sub sistem, antara lain : efektivitas keputusan, produktivitas individu, pembelajaran dan kegunaan.

Pengumpulan Data Kuesioner dan Analisis Data

Metode Kuesioner digunakan untuk memperoleh data dengan memberikan pertanyaan tertulis kepada pelanggan Toko Hijab Amira Surakarta tentang 28 variabel-variabel pelayanan yang diterima yang terdiri dari : 5 pertanyaan kualitas sistem, 9 pertanyaan kualitas informasi, 5 pertanyaan kualitas pelayanan, 3 pertanyaan kualitas pengguna, 2 
pertanyaan intensitas untuk menggunakan aplikasi fashion hijab/user, 4 pertanyaan net benefit. Pertanyaan dalam kuesioner disusun dengan menggunakan skala likert dengan pendekatan 5 skala yaitu sangat tidak puas, tidak puas, ragu-ragu, puas, sangat puas. Hasil dari kuesioner tersebut akan dianalisis untuk menentukan hipotesis dari penelitian ini. Pengumpulan data dilakukan dua kali, pengumpulan data pertama dilakukan untuk melihat indikator variabel dalam kuesioner. Penyebaran dan pengumpulan data dilakukan dengan menggunakan sampel kecil dari pelanggan Toko Hijab Amira Surakarta. Selanjutnya dilakukan uji validitas dan uji reliabilitas untuk mengetahui apakah data kuesioner layak digunakan dalam penelitian. Jika data kuesioner sudah valid dan reliabel maka dapat dilakukan tahap berikutnya yaitu analisis data, jika data kuesioner tidak valid dan reliabel maka akan dilakukan pengumpulan data kembali dan evaluasi hingga data kuesioner layak digunakan untuk penelitian. Pengumpulan data kuesioner kedua dilakukan setelah data kuesioner dinyatakan sudah valid dan reliabel. Penyebaran kuesioner dilakukan setelah implementasi aplikasi fashion hijab. Sampel responden pada penelitian setelah implementasi aplikasi fashion hijab diambil $30 \%$ dari populasi pelanggan Toko Hijab Amira Surakarta (Arikunto, 2008) yaitu 70 pelanggan Toko Hijab Amira Surakarta yang telah memiliki kartu pelanggan dan aktif berbelanja di Toko Hijab Amira Surakarta selama satu tahun terakhir.

Setelah melakukan pengumpulan data, selanjutnya peneliti akan melakukan analisis data statistik deskriptif untuk mengetahui informasi data kuesioner yang sudah terkumpul dan analisis statistik multivariat untuk pengujian hipotesis data hasil kuesioner dengan SEM (Structural Equation Modelling) menggunakan aplikasi Smart PLS (Smart Partial Least Square).

\section{HASIL DAN LUARAN YANG DICAPAI}

Pembuatan Aplikasi Fashion Hijab

Berikut ini merupakan tampilan dari website toko online Hijab Amira.com

1. Tampilan website toko online

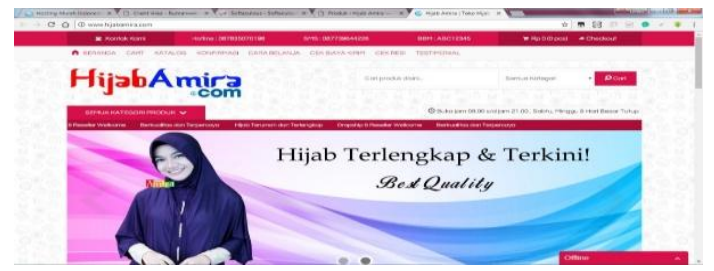

Gambar 3. Tampilan Website Toko Online

2. Tampilan Produk pada halaman utama toko online

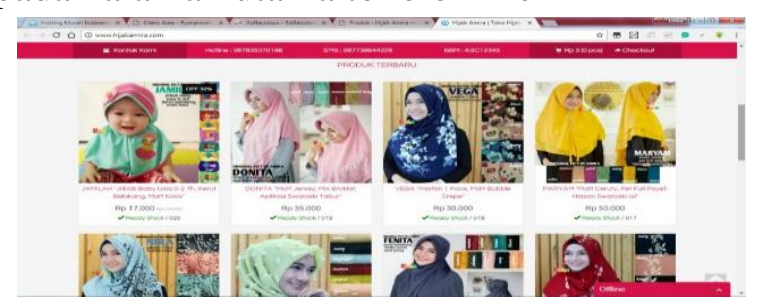

Gambar 4. Tampilan Produk Pada Halaman Utama Toko Online 
3. Berikut ini adalah tampilan pada Aplikasi Android Hijab Amira

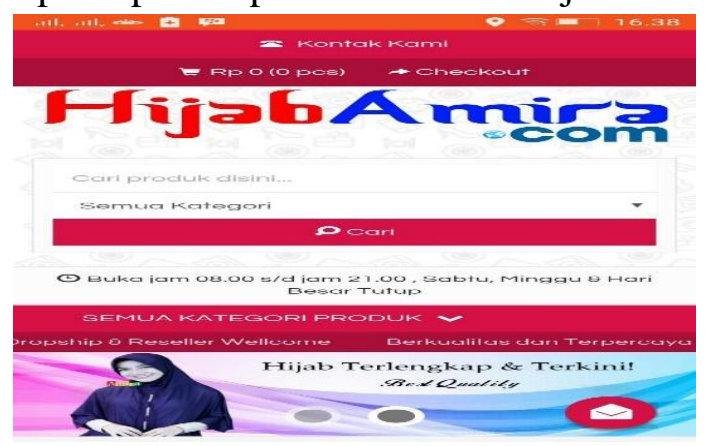

Gambar 5. Tampilan Pada Aplikasi Android Hijab Amira

4. Berikut ini adalah tampilan produk pada halaman utama

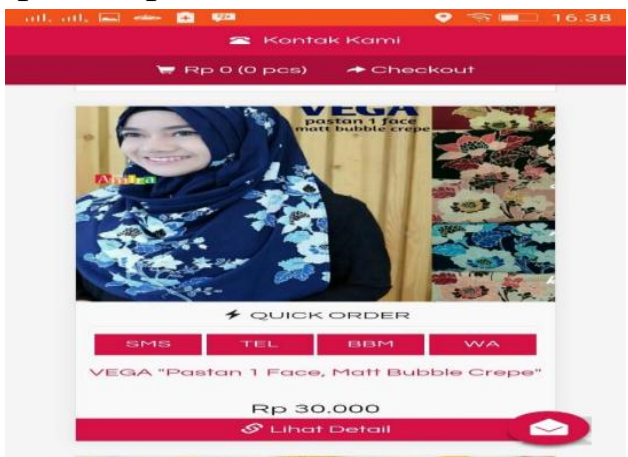

Gambar 6. Tampilan Produk Pada Halaman Utama Aplikasi Android

Implementasi

Selanjutnya dilakukan implementasi dengan membagikan aplikasi fashion hijab kepada pelanggan Toko Hijab Amira Surakarta yang sudah memiliki kartu pelanggan. Implementasi dilakukan selama 2 bulan yaitu bulan Mei 2018 - Juni 2018, tahap selanjutnya adalah melakukan pengumpulan data dengan menyebarkan kuesioner kepada pelanggan Toko Hijab Amira Surakarta.

\section{Hasil Pengumpulan Data}

Pengumpulan data dilakukan pada bulan Juli 2018 dengan menggunakan metode kuesioner yang telah disebarkan kepada 70 pelanggan yang dianggap dapat mewakili populasi pelanggan di Toko Hijab Amira Surakarta. Penyebaran kuesioner bertujuan untuk mengetahui apakah terdapat peningkatan kualitas pelayanan setelah implementasi aplikasi fashion hijab berbasis android di Toko Hijab Amira Surakarta.

\section{Uji Instrumen Pengumpulan Data}

Uji instrumen pengumpulan data dilakukan untuk mengetahui apakah hasil pengumpulan data sudah layak digunakan dalam penelitian. Pada tahap ini dilakukan uji validitas dan reliabilitas terhadap hasil pengumpulan data kuesioner. 
Tabel 7. Hasil Uji Validitas dan Uji Reliabilitas Kuesioner Penelitian

\begin{tabular}{|c|c|c|c|c|c|}
\hline \multirow[b]{2}{*}{ Variabel } & \multirow[b]{2}{*}{ Indikator } & \multicolumn{2}{|c|}{ Uji Validitas } & \multicolumn{2}{|c|}{ Uji Reliabillitas } \\
\hline & & $\begin{array}{c}\text { Nilai } \\
\text { Korelasi }\end{array}$ & $\begin{array}{c}\text { Kesim- } \\
\text { pulan }\end{array}$ & $\begin{array}{c}\text { Cronbach } \\
\text { Alpha }\end{array}$ & $\begin{array}{l}\text { Kesim- } \\
\text { pulan }\end{array}$ \\
\hline \multirow{2}{*}{$\begin{array}{l}\text { Kualitas sistem } \\
\text { (system quality) }\end{array}$} & \multirow{2}{*}{ Fungsionalitas } & 0,672 & Valid & \multirow[b]{2}{*}{0,830} & \multirow[b]{2}{*}{ Reliabel } \\
\hline & & 0,827 & Valid & & \\
\hline \multirow{3}{*}{$\begin{array}{l}\text { Kualitas sistem } \\
\text { (system quality) }\end{array}$} & Kehandalan & 0,754 & Valid & \multirow[b]{3}{*}{0,830} & \\
\hline & Kegunaan & 0,593 & Valid & & \multirow[b]{2}{*}{ Reliabel } \\
\hline & Aksesibilitas & 0,381 & Valid & & \\
\hline \multirow{9}{*}{$\begin{array}{l}\text { Kualitas Informasi } \\
\text { (information quality) }\end{array}$} & Informatif & 0,438 & Valid & \multirow{9}{*}{0,877} & \multirow{10}{*}{ Reliabel } \\
\hline & Ketepatan waktu & 0,598 & Valid & & \\
\hline & Periode waktu & 0,627 & Valid & & \\
\hline & Relevansi & 0,581 & Valid & & \\
\hline & Kelengkapan & 0,658 & Valid & & \\
\hline & Kejelasan & 0,642 & Valid & & \\
\hline & Kerincian & 0,602 & Valid & & \\
\hline & Tersusun & 0,733 & Valid & & \\
\hline & Penyajian & 0,780 & Valid & & \\
\hline \multirow{5}{*}{$\begin{array}{l}\text { Kualitas pelayanan } \\
\text { (service quality) }\end{array}$} & Tangibel & 0,664 & Valid & \multirow{5}{*}{0,831} & \\
\hline & Reability & 0,631 & Valid & & \multirow{4}{*}{ Reliabel } \\
\hline & Responsi-veness & 0,610 & Valid & & \\
\hline & Assurance & 0,619 & Valid & & \\
\hline & Emphaty & 0,667 & Valid & & \\
\hline \multirow{3}{*}{$\begin{array}{c}\text { Kepuasan Pengguna } \\
\text { (user satisfaction) }\end{array}$} & Akurasi & 0,927 & Valid & \multirow{3}{*}{0,935} & \multirow{3}{*}{ Reliabel } \\
\hline & Konten & 0,863 & Valid & & \\
\hline & Format & 0,811 & Valid & & \\
\hline \multirow{2}{*}{$\begin{array}{c}\text { Intensitas untuk } \\
\text { menggunakan aplikasi } \\
\text { fashion hijab (user) }\end{array}$} & Frekuensi & 0,76 & Valid & \multirow[b]{2}{*}{0,861} & \multirow[b]{2}{*}{ Reliabel } \\
\hline & Durasi waktu & 0,76 & Valid & & \\
\hline
\end{tabular}

Tabel 7. Hasil Uji Validitas dan Uji Reliabilitas Kuesioner Penelitian (Lanjutan)

\begin{tabular}{|c|c|c|c|c|c|}
\hline \multirow[b]{2}{*}{ Variabel } & \multirow[b]{2}{*}{ Indikator } & \multicolumn{2}{|c|}{ Uji Validitas } & \multicolumn{2}{|c|}{ Uji Reliabillitas } \\
\hline & & $\begin{array}{c}\text { Nilai } \\
\text { Korelasi }\end{array}$ & $\begin{array}{l}\text { Kesim- } \\
\text { pulan }\end{array}$ & $\begin{array}{c}\text { Cronbach } \\
\text { Alpha }\end{array}$ & $\begin{array}{l}\text { Kesim- } \\
\text { pulan }\end{array}$ \\
\hline \multirow{4}{*}{ Net Benefit } & $\begin{array}{l}\text { Efektivitas } \\
\text { keputusan }\end{array}$ & 0,752 & Valid & \multirow{4}{*}{0,752} & \multirow{4}{*}{ Reliabel } \\
\hline & $\begin{array}{l}\text { Produktivitas } \\
\text { individu }\end{array}$ & 0,497 & Valid & & \\
\hline & Pembelajaran & 0,533 & Valid & & \\
\hline & Kegunaan & 0,598 & Valid & & \\
\hline
\end{tabular}

\section{Analisis Statistik Deskriptif}

Analisis statistik deskriptif digunakan untuk memberikan informasi terkait dengan pengumpulan dan penyajian data hasil kuesioner. Data responden yang diperoleh sebanyak 70 responden. Proses perhitungan analisis deskriptif ini menggunakan mean atau rata-rata dari data hasil kuesioner masing-masing variabel, sehingga dapat diperoleh gambaran 
tentang jawaban dari pelanggan Toko Hijab Amira Surakarta sebagai responden penelitian. Rentang kategori jawaban responden adalah sebagai berikut :

Tabel 8. Rentang Mean Jawaban Responden

\begin{tabular}{cc}
\hline Rentang Mean & Keterangan \\
\hline $1=0-1$ & Sangat Tidak Puas \\
$2=1,1-2$ & Tidak Puas \\
$3=2,1-3$ & Ragu-Ragu \\
$4=3,1-4$ & Puas \\
$5=4,1-5$ & Sangat Puas \\
\hline
\end{tabular}

Hasil dari rekapitulasi perhitungan data hasil kuesioner untuk analisis deskriptif adalah sebagai berikut :

Tabel 9. Hasil Analisis Deskriptif

\begin{tabular}{|c|c|c|}
\hline Variabel & Pertanyaan Kuesioner & Mean \\
\hline Kualitas Sistem & $\begin{array}{l}\text { Performansi/kinerja sistem dari aplikasi } \\
\text { fashion hijab }\end{array}$ & 4,36 \\
\hline Kualitas Informasi & $\begin{array}{l}\text { Periode waktu dalam memberikan } \\
\text { informasi terbaru }\end{array}$ & 4,57 \\
\hline Kualitas Pelayanan & $\begin{array}{l}\text { pelayanan Toko Hijab Amira Surakarta } \\
\text { dalam menangani kebutuhan pelanggan }\end{array}$ & 4,36 \\
\hline \multicolumn{3}{|c|}{ Tabel 9. Hasil Analisis Deskriptif (Lanjutan) } \\
\hline Variabel & Pertanyaan Kuesioner & Mean \\
\hline Kepuasan Pengguna & Keakuratan aplikasi fashion hijab & 4,33 \\
\hline User & $\begin{array}{l}\text { Durasi/lama pemakaian aplikasi fashion } \\
\text { hijab oleh pengguna }\end{array}$ & 4,4 \\
\hline net benefit & $\begin{array}{l}\text { Kemudahan dalam penggunaan secara } \\
\text { keseluruhan aplikasi fashion hijab }\end{array}$ & 4,13 \\
\hline
\end{tabular}

\section{Structural Equation Modell (SEM)}

Setelah melakukan pengujian validitas, reliabilitas dan analisis statistik deskriptif pada hasil penelitian. Langkah selanjutnya adalah melakukan pengujian Structural Equation Modell (SEM) dengan menggunakan Smartpls.

Hasil Penelitian Uji Hipotesis

Berdasarkan rumusan hipotesis dilakukan uji hipotesis dengan menggunakan structural equation modell. Berikut merupakan model penelitian dengan menggunakan structural equation modell.

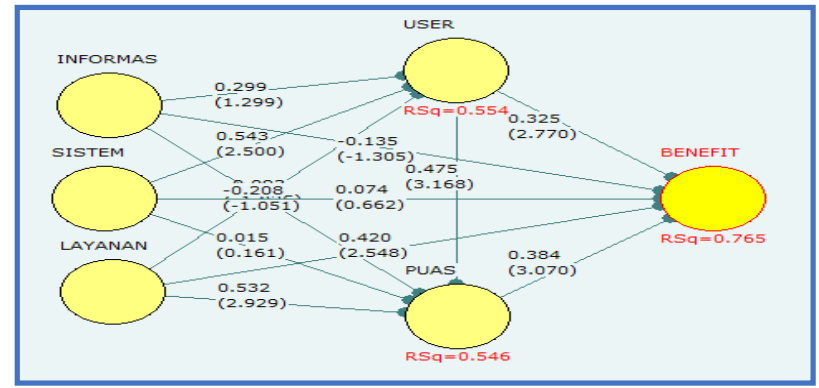

Gambar 7. Model Penelitian Dengan Menggunakan Structural Equation Modell 
Tabel berikut merupakan hasil hipotesis dari pengujian structural equation modell dengan menggunakan SmartPLS.

Tabel 10. Hasil dari Structural Equation Modell

\begin{tabular}{lcc}
\hline \multicolumn{1}{c}{ Hubungan Variabel } & T-Statistic & Keterangan \\
\hline Information $\rightarrow$ User & 1,020 & \\
Informatin $\rightarrow$ Satisfaction & $-1,036$ & $\mathrm{H}_{1}$ ditolak \\
Systems $\rightarrow$ User & 2,331 & $\mathrm{H}_{2}$ ditolak \\
Systems $\rightarrow$ Satisfaction & 0,063 & $\mathbf{H}_{\mathbf{3}}$ diterima \\
Service $\rightarrow$ User & $-0,231$ & $\mathrm{H}_{4}$ ditolak \\
Service $\rightarrow$ Satisfaction & 2,836 & $\mathrm{H}_{5}$ ditolak \\
User $\rightarrow$ Satisfaction & 3,066 & $\mathbf{H}_{\mathbf{6}}$ diterima \\
User $\rightarrow$ Net Benefit & 2,330 & $\mathbf{H}_{\mathbf{7}}$ diterima \\
Satisfaction $\rightarrow$ Net Benefit & 3,136 & $\mathbf{H}_{\mathbf{8}}$ diterima \\
Information $\rightarrow$ Net Benefit & $-0,541$ & $\mathbf{H}_{\mathbf{9}}$ diterima \\
System $\rightarrow$ Net Benefit & $-3,896$ & $\mathrm{H}_{10}$ ditolak \\
Service $\rightarrow$ Net Benefit & 2,884 & $\mathbf{H}_{\mathbf{1 1}}$ diterima \\
Infor $\rightarrow$ User $\rightarrow$ Net Benefit & 0,938 & $\mathbf{H}_{\mathbf{1 2}}$ diterima \\
System $\rightarrow$ User $\rightarrow$ Net Benefit & 1,714 & $\mathrm{H}_{13}$ ditolak \\
Service $\rightarrow$ User $\rightarrow$ Net Benefit & $-0,694$ & $\mathbf{H}_{\mathbf{1 4}}$ diterima \\
Infor $\rightarrow$ Satis $\rightarrow$ Net Benefit & $-0,976$ & $\mathrm{H}_{15}$ ditolak \\
System $\rightarrow$ Satis $\rightarrow$ Net Benefit & 0,094 & $\mathrm{H}_{16}$ ditolak \\
Service $\rightarrow$ Satis $\rightarrow$ Net Benefit & 1,785 & $\mathrm{H}_{17}$ ditolak \\
\hline
\end{tabular}

\section{KESIMPULAN}

Berdasarkan hasil analisis pengolahan data diatas dapat diambil kesimpulan bahwa tingkat kesuksesan implementasi aplikasi fashion hijab di Toko Hijab Amira Surakarta dengan menggunakan aplikasi android pada variabel kualitas sistem dengan nilai rata-rata dari hasil kuesioner 4,36 yang memiliki keunggulan pada performansi/kinerja sistem dari aplikasi fashion hijab. Variabel kualitas informasi dengan nilai rata-rata dari hasil kuesioner 4,57 yang memiliki keunggulan pada periode waktu dalam memberikan informasi terbaru. Variabel kualitas pelayanan dengan nilai rata-rata dari hasil kuesioner 4,36 yang menunjukkan bahwa aplikasi fashion hijab di Toko Hijab Amira Surakarta memiliki pengaruh yang besar dalam membantu pelayanan Toko Hijab Amira Surakarta dalam menangani kebutuhan pelanggan. Variabel kepuasan pengguna dengan nilai ratarata dari hasil kuesioner 4,33 yang memiliki keunggulan pada keakuratan aplikasi fashion hijab. Variabel net benefit dengan nilai rata-rata dari hasil kuesioner 4,4 yang memiliki keunggulan pada durasi/lama pemakaian aplikasi fashion hijab oleh pengguna. Variabel kepuasan pengguna dengan nilai rata-rata dari hasil kuesioner 4,13 yang memiliki keunggulan pada kemudahan dalam penggunaan secara keseluruhan aplikasi fashion hijab. 
Berdasarkan 18 hipotesis penelitian terdapat 7 hipotesis yang mempengaruhi net benefit, yaitu : Kualitas sistem (systems quality) berpengaruh signifikan dan positif terhadap pengguna sistem (user), kualitas pelayanan (service quality) berpengaruh signifikan dan positif terhadap kepuasan pengguna sistem (user satisfaction), pengguna sistem (user) berpengaruh signifikan dan positif terhadap kepuasan pengguna sistem (user satisfaction), pengguna sistem (user) berpengaruh signifikan dan positif terhadap pengguna sistem (user), kepuasan pengguna sistem (user satisfaction) berpengaruh signifikan dan positif terhadap hasil akhir (net benefit), kualitas sistem (systems quality) berpengaruh signifikan dan positif terhadap hasil akhir (net benefit), kualitas pelayanan (service quality) berpengaruh signifikan dan positif terhadap hasil akhir (net benefit)

Aplikasi fashion hijab Toko Hijab Amira Surakarta masih memerlukan perbaikan pada beberapa variabel, antara lain : kualitas informasi dan kualitas sistem. Rekomendasi yang dapat diberikan pada aplikasi fashion hijab Toko Hijab Amira Surakarta antara lain penggunaan aplikasi fashion hijab dapat difungsikan secara lebih maksimal ke pelanggan Toko Hijab Amira Surakarta, aplikasi fashion hijab perlu diperbaiki lagi dalam hal kemudahan dalam penggunaan dan kompatibel dengan semua peramban dan peralatan teknologi gadget, penampilan dari aplikasi fashion hijab perlu lebih rinci dan tersusun lebih rapi lagi sehingga lebih mudah digunakan oleh pelanggan Toko Hijab Amira Surakarta.

Dengan adanya rekomendasi diatas, diharapkan aplikasi fashion hijab dapat lebih efektif dan lebih mudah digunakan oleh pelanggan Toko Hijab Amira Surakarta, sehingga tingkat kepuasan pelanggan Toko Hijab Amira Surakarta lebih baik lagi.

\section{DAFTAR PUSTAKA}

Arikunto, S. 2008. Prosedur Penelitian Suatu Pendekatan Praktek. Rineka Cipta. Jakarta.

Chin, W. W. dan P. A. Todd, 1995, "On the Use, Usefulness, and Ease of Use of Structural Equation Modeling in MIS Research: A Note of Caution”, MIS Quarterly, 19: 237246.

Choi, E. J., \& Kim, S. 2013. The Study of the Impact of Perceived Quality and Value of Social Enterprises on Customer Satisfaction and Re-Purchase Intention, 7(1), 239252.

Davis, F. D., 1989, "Perceived Usefulness, Perceived Ease of Use, and User Acceptance of Information Technology”, MIS Quarterly, 13/3: 319-339.

DeLone, W. H., \& McLean, E. R. 2008. Measuring information systems success: models, dimensions, measures, and interrelationships. European Journal of Information Systems, $\quad 17, \quad 236-263$. http://citeseerx.ist.psu.edu/viewdoc/download?doi=10.1.1.462.7377\&rep=rep1\&type= pdf. Diakses tanggal 24 Januari 2017. 
Ferdinand. A. 2002. Structural Equation Modelling dalam Penelitian Manajemen. Semarang: FE UNDIP.

Ghozali I. 2008. Structural Equation Modelling Metode Alternatif dengan Partial Least Square. Edisi 2. Badan Penerbit Universitas Diponegoro. Semarang.

Hanif Al Fatta. 2007. Analisis dan Perancangan Sistem Informasi. Andi. Yogyakarta.

HpArea. 2016. Apa itu Android?? Pengertian, Kelebihan serta Kekurangan Internet. http ://www.hparea.com/pengertian-kelebihan-kekurangan android.html. Diakses tanggal 10 Agustus 2016.

Jogiyanto, H.M. 2005. "Aplikasi dan Desain Sistem Informasi : Pendekatan Terstruktur, Teori dan Praktik Aplikasi Bisnis". Penerbit Andi.Yogyakarta.

Jogiyanto, 2007, Sistem Informasi Keperilakuan, Edisi Revisi, Penerbit Andi.Yogyakarta. Jogiyanto 2007, Model Kesuksesan Sistem Teknologi Informasi. Penerbit Andi.Yogyakarta.

Jogiyanto (2010) Metode Penelitian Bisnis. BPFE UGM. Yogyakarta

Kotler, P. 2005. Manajemen Pemasaran. Penerbit Salemba Empat. Jakarta.

Kotler P, Armstrong G. 2008. Prinsip-Prisip Pemasaran, Jilid 1. Penerbit Erlangga. Jakarta

Kristiono \& Honggo,Henky.,2015. Analisis Pengaruh Kualitas Informasi Website Terhadap Minat Beli Ulang Pelanggan Belanja Online. Jurnal Jurusan Sistem Informasi STMIK GI MDP Palembang. http://eprint.mdp.ac.id/1354/. Diakses tanggal 23 Januari 2017.

Lalage, Zerlina. 2014. Sweet Smart Sexy \& Beautiful. Penerbit Galmas Publisher.Klaten.

Liu, C. and Arnett, K. 2000. Exploring the Factors Associated with Web Site Success in the Context of Electronic Commerce. Information \& Management, 38, 23-33.

Nazruddin, Safaat. 2012. Pemograman Aplikasi Mobile. Smartphone dan Tablet PC Berbasis Android. Informatika. Bandung.

N. Sora. 2015. Pengertian Fashion. http://www.pengertianku.net/2015/11/definisi-ataupengertian fashion-secara-umum.html. Diakses tanggal 29 September 2016.

O'Brien, James, 2005, Pengantar Sistem Informasi Perspektif Bisnis dan. Manajerial. Salemba Empat. Jakarta.

Prayitno, Sugeng. 2013. Basic4Android. www.scribd.comm/doc/160147846/Basic-4Android. Diakses tanggal 10 Agustus 2016.

Radityo. D \& Zulaikha. (2007). Pengujian Model DeLone and McLean Dalam Pengembangan Sistem Informasi Manajemen (Kajian Sebuah Kasus). Simposium Nasional Akutansi X (SNA X) tanggal 26 - 28 Juli 2007. Universitas Hasanuddin Makasar. http:// http://eprints.undip.ac.id/15193/1/SI-_05.pdf. Diakses tanggal 24 Januari 2017.

Rai,A.,Lang,S.S..,Welker,R.B., 2002, Assessing the validity is success models : an empirical test and theoritical analysis. Information systems research 13, 50-69. 


\section{JURNAL NUSAMBA VOL.3 NO.2 Oktober 2018}

Ridwan. 2005. Skala Pengukuran Variabel-Variabel Penelitian. Penerbit Alfabeta. Bandung.

Safaat, Nazarudin. 2012. Pemrograman Aplikasi Mobile Smartphone dan Tablet PC Berbasis Android. Penerbit Informatika.Bandung.

Sugiyono. 2012.Metode Penelitian Kuantitatif Kualitatif dan RD. Penerbit Alfabeta. Bandung.

Suprapto, J. 1997. Pengukuran Tingkat Kepuasan Pelanggan. Penerbit PT. Rineka Cipta.Jakarta.

Tjiptono,Fandy. 2005. Pemasaran Jasa. Penerbit Bayumedia Publishing.Malang.

Wahyudi, R.,Astuti, 2012, Pengaruh Kualitas Sistem, Informasi dan Kualitas SIAKAD terhadap Kepuasan Mahasiswa, Jurnal Administrasi Bisnis, Vol. 1, No. 1.

Wang, Y. S., \& Liao, Y. W. 2008. Assessing eGovernment systems success: A validation of the DeLone and McLean model of information systems success. Government Information Quarterly, 25, 717-733. doi:10.1016/j.giq.2007.06.002 